\title{
Implication of corticotropic hormone axis in eating behaviour pattern in obese and type 2 diabetic participants
}

\author{
Hassiba Benbaibeche ${ }^{1}$, El Mahdi Haffaf ${ }^{2}$, Ghouti Kacimi ${ }^{3}$, Brahim Oudjit ${ }^{4}$, Naim Akhtar Khan ${ }^{5 *}$ and \\ Elhadj Ahmed Koceïr ${ }^{1}$ \\ ${ }^{1}$ Laboratoire de Bioénergétique et Métabolisme Intermédiaire, Faculté des Sciences Biologiques, Université des Sciences \\ et de la Technologie Houari Boumediene, Alger, Algérie \\ ${ }^{2}$ Service de Médecine Nucléaire, CHU-Hôpital Mohamed Seghir Nekache, Alger, Algérie \\ ${ }^{3}$ Laboratoire de Biochimie, CHU-Hôpital Mohamed Seghir Nekache, Alger, Algérie \\ ${ }^{4}$ Service de Diabétologie, CHU-Hôpital Mohamed Seghir Nekache, Alger, Algérie \\ ${ }^{5}$ Physiologie de la Nutrition \& Toxicologie, UMR U866 INSERM/Université de Bourgogne/Agro-Sup, \\ 6 Boulevard Gabriel, Dijon 21000, France \\ (Submitted 27 July 2014 - Final revision received 12 January 2015 - Accepted 3 February 2015 - First published online 18 March 2015)
}

\section{Abstract}

In Algeria, eating behaviour has been increasingly deviated from its traditional Mediterranean diet to modern fast food style. The present study examines the interactions between eating behaviour pattern (EBP), corticotropic hormone axis and the metabolic syndrome. Our Algerian population cohort comprised of 410 participants (130 obese, 170 type 2 diabetics and 110 healthy participants). The EBP was evaluated by the Three-Factor Eating Questionnaire test. The anthropometric and metabolic parameters (glucose, TAG, HDL, LDL and cholesterol) and the concentrations of hormones (insulin, adrenocorticotropin hormone (ACTH), cortisol and growth hormone) were determined by biometrics, spectrophotometry and RIA, respectively. Multivariate analyses showed a high correlation between the EBP and the metabolic syndrome, particularly between insulin-resistant state and hypertrophy of visceral adipose tissue. Compared with healthy participants, obese ones showed the hyperphagic type of EBP, i.e. disinhibition and hunger disorders. Conversely, the diabetics showed both the hypophagic and hyperphagic type of EBP. In diabetic and obese participants, cortisol and ACTH secretions were significantly altered, leading to metabolic disorders. The present study confirms the role of EBP in obesity and diabetes.

Key words: Metabolic syndrome: Insulin resistance: Eating behaviour patterns: Type 2 diabetes: Obesity

Food ingestion and energy expenditure maintain body weight and energy reserves for the adaptation of an organism to its environment and to respond to sudden changes of food scarcity $^{(1)}$. Eating behaviour is modulated by several factors such as palatability, odour and texture of foods, and also by emotional situations such as stress and anxiety ${ }^{(2)}$. High consumption of palatable and energy-rich food largely contributes to eating behaviour disorders. Hence, food intake responds to hedonic requirement in addition to hunger signals, and consequently, an organism develops overeating that might contribute to obesity and type 2 diabetes, known to be associated with a perturbation in hypothalamic satiety and hunger centres ${ }^{(3)}$.

At present, there are 1.6 billion overweight subjects and 400 million obese subjects ${ }^{(4)}$. The prevalence of diabetes in Algeria has increased from $6 \cdot 8 \%$ in 1990 to $12 \cdot 29 \%$ in 2005 , but is quite higher among certain groups and areas of the country $^{(5)}$. This disease affects all population groups, especially 35- to 70-year-olds, who constitute a large segment of the working population in Algeria ${ }^{(5)}$. Although the susceptibility to develop type 2 diabetes is based, in part, on genetic predisposition $^{(6)}$, dietary habits play a key role in its pathogenesis. The Mediterranean diet has been shown to be associated with better glycaemic control in patients with newly diagnosed diabetes ${ }^{(7)}$. Another study has shown that the Mediterranean diet had a protective effect against diabetes ${ }^{(8)}$.

The concept of restrained eating is originally introduced to define a type of eating behaviour pattern (EBP) governed by cognitive processes rather than by physiological mechanisms such as hunger and satiety ${ }^{(9)}$. As measured by the activation of corticotropic axis (CA) during behaviour disorders

Abbreviations: $11 \beta$-HSD-1, 11ß-hydroxysteroid dehydrogenase-1; ACTH, adrenocorticotropin hormone; CA, corticotropic axis; EBP, eating behaviour pattern; GH, growth hormone; TFEQ, Three-Factor Eating Questionnaire; WC, waist circumference.

*Corresponding author: Dr N. A. Khan, fax +33 3803963 30, email naim.khan@u-bourgogne.fr 
related to eating pattern/habits, restrictive eating has been found to be a causal factor for high secretion of cortisol ${ }^{(10)}$. Boullu-Ciocca et al. ${ }^{(11)}$ reported that activation of CA might contribute to the development of insulin resistance and metabolic syndrome in the EBP. Brindley \& Rolland ${ }^{(12)}$ proposed that there might be a relationship between stress-induced hormones and the metabolic syndrome. In stressful conditions, glucocorticoids (GC), released by CA, might decrease energy expenditure and, together with insulin, promote energy deposition. These observations provide a partial explanation for the metabolic changes that can accompany the risk factors for diabetes and atherosclerosis. Duong et al. ${ }^{(13)}$ explored the relationship between cortisol levels, poor blood glucose control and food quality choice in diabetic patients. These authors reported that there exists a relationship between glycosylated $\mathrm{Hb}(\mathrm{HbA1c})$ concentrations and low-quality food choice that is mediated by cortisol via poor control of hypothalamic-pituitary-adrenal axis in diabetic patients ${ }^{(13)}$.

GC have been shown to exert either stimulatory or inhibitory actions on growth hormone (GH) secretion by influencing both hypothalamic and pituitary functions ${ }^{(14)}$. GC exert negative effects via hypothalamus by inhibiting growth hormonereleasing hormone (GHRH), and stimulating synthesis and release of somatostatin ${ }^{(15)}$. In contrast, GC via pituitary have been shown to stimulate $\mathrm{GH}^{(16)}$ and $\mathrm{GHRH}$ receptor gene expression ${ }^{(17)}$. High concentrations of cortisol have been shown to decrease peripheral GH levels ${ }^{(18)}$, and small increases in cortisol concentrations exert a stimulatory effect on GH secretion by increasing GH mRNA levels ${ }^{(19)}$. GC therapy perturbs $\mathrm{GH} /$ insulin-like growth factor 1 axis by decreasing hepatic GH receptor and plasma levels of $\mathrm{GH}$ binding proteins ${ }^{(20)}$. However, no study is available on the interrelationship between activation of $\mathrm{CA}, \mathrm{GH}$ secretion and type 2 diabetes along with obesity. In the present study, we, therefore, tried to shed light on the implication of $\mathrm{CA}$ in obese and diabetic Algerian participants in relation with EBP.

\section{Materials and methods}

\section{Subjects}

The present study included age-matched 410 participants who were divided into four groups, i.e. 170 patients with type 2 diabetes (seventy-six normal-weight diabetics and ninety-four overweight diabetics), 130 obese participants and 110 healthy participants. The study was followed-up in the Diabetology Department, Mohamed-Seghir Nekache Hospital, Algiers. The exclusion criteria were cardiovascular or renal or any other complications, smoking habits and any medical treatment that may alter feeding behaviour. All participants were followedup for the nutritional education in a daily hospital consultation. The diabetics received a treatment as per indication of $\mathrm{HbA} 1 \mathrm{c}$ levels. Subjects with HbA1c level $<7 \%$ were given metformin (twice, $850 \mathrm{mg} / \mathrm{d}$ ), and those with HbA1c level $>7 \%$ were given metformin (twice, $850 \mathrm{mg} / \mathrm{d}$ ) plus Daonil (twice, $2.5 \mathrm{mg} / \mathrm{d}$ ). A fact sheet was prepared for the diagnosis of any complications in the recruited participants. The participants were interrogated for any family history of obesity and diabetes. Drug dosages were stable for at least 3 months. Throughout the study, no microbial infections were noticed. The duration of diabetes varied between 5 and 15 years. The study was conducted between 1 January 2010 and 31 March 2013. The clinical protocol was approved by the ethics committee of the Algerian Ministry of Public Health according to the Declaration of Helsinki.

\section{Three-Factor Eating Questionnaire}

The test of Three-Factor Eating Questionnaire (TFEQ) was considered as the most reliable approach for the evaluation of $\mathrm{EBP}^{(21)}$. The TFEQ contains fifty-one questions or test items, twenty-one questions represent the cognitive restriction (R), sixteen represent disinhibition (D) and fourteen correspond to 'susceptibility' to hunger $(\mathrm{H})$. As per scores, R, D and $\mathrm{H}$ were considered as low if the values were $0-10,0-8$ and $0-7$, respectively $^{(21)}$. The values $>10,>8$ and $>7$ of $R, D$ and $H$, respectively, were considered to be high ${ }^{(21)}$. The results are presented as mean scores.

The TFEQ is based on distinct components of eating behaviour: restraint; disinhibition; hunger. Restraint reflects the degree to which a person exerts behavioural control over his own eating behaviour. Dietary restraint refers to limit the food intake in order to maintain the body weight. It represents the cognitive control of eating behaviour, contrary to physiological control, such as hunger and satiety. Disinhibition is an eating behaviour trait associated with overeating and eating opportunistically. Dietary disinhibition is usually prevalent in subjects who are food restricted but lose control in response to certain stimuli such as food

Table 1. Eating behaviour pattern in healthy, obese and diabetic participants

(Mean values and standard deviations)

\begin{tabular}{|c|c|c|c|c|c|c|c|c|}
\hline \multirow[b]{3}{*}{ TFEQ } & \multirow{2}{*}{\multicolumn{2}{|c|}{$\begin{array}{l}\text { Healthy } \\
\text { participants } \\
(n 110)\end{array}$}} & \multirow{2}{*}{\multicolumn{2}{|c|}{$\begin{array}{c}\text { Obese } \\
\text { participants } \\
(n 130)\end{array}$}} & \multicolumn{4}{|c|}{ Diabetic participants } \\
\hline & & & & & \multicolumn{2}{|c|}{$\begin{array}{c}\text { Normal weight } \\
(n 76)\end{array}$} & \multicolumn{2}{|c|}{$\begin{array}{l}\text { Overweight } \\
(n 94)\end{array}$} \\
\hline & Mean & SD & Mean & SD & Mean & SD & Mean & SD \\
\hline Restraint & $4 \cdot 2$ & 0.52 & 4.5 & 0.66 & $8 \cdot 67^{\star \star}$ & 1.15 & $9 \cdot 09^{\star \star}$ & 0.68 \\
\hline Disinhibition & $5 \cdot 0$ & 0.33 & $9 \cdot 45^{\star *}$ & 0.42 & $5 \cdot 78^{\star}$ & 0.7 & $6 \cdot 64^{*}$ & 0.89 \\
\hline Hunger & 3.95 & 0.33 & $6 \cdot 25^{\star}$ & 0.26 & $5 \cdot 22^{*}$ & 0.88 & $6 \cdot 73^{*}$ & 0.93 \\
\hline
\end{tabular}

TFEQ, Three-Factor Eating Questionnaire.

Mean values were significantly different from that of the healthy participant group: ${ }^{*} P<0.05,{ }^{* *} P<0.01$. 
Table 2. Eating behaviour pattern correlation with $\mathrm{BMI}$ in obese and diabetic participants

\begin{tabular}{lccc}
\hline \multicolumn{3}{c}{ TFEQ factors $(r$ values) } \\
\hline Participants & Restriction & Disinhibition & Hunger sensation \\
\hline Obese $(n$ 130) & -0.15 & $0.51^{\star *}$ & 0.28 \\
$\begin{array}{c}\text { Normal-weight } \\
\text { diabetics }(n \text { 76) }\end{array}$ & -0.12 & $0.38^{\star}$ & 0.13 \\
$\begin{array}{c}\text { Overweight } \\
\text { diabetics }(n \text { 94) }\end{array}$ & -0.18 & $0.53^{\star *}$ & 0.21 \\
\hline
\end{tabular}

TFEQ, Three-Factor Eating Questionnaire; $r$, correlation coefficient.

${ }^{*} P<0.05$.

${ }^{\star *} P<0.01$

palatability $^{(22)}$, anxiety or depressed $\operatorname{mood}^{(23)}$. Hunger, in relation to the TFEQ, reflects a person's stable underlying sensitivity to hunger feelings and predisposition to eat ${ }^{(24)}$.

\section{Metabolic syndrome criteria}

In the present study, the definition of metabolic syndrome followed the criteria of the National Cholesterol Education Program-Adult Treatment Panel III (NCEP-ATPIII) as described by Athyros et al. ${ }^{(25)}$. These metabolic syndrome criteria apply if three out of five risk factors are met in the subjects ${ }^{(26)}$, i.e. (1) TAG: $\geq 1.69 \mathrm{mmol} / \mathrm{l}(1.50 \mathrm{~g} / \mathrm{l})$; (2) HDL-cholesterol: men, $<1.04 \mathrm{mmol} / \mathrm{l} \quad(0.40 \mathrm{~g} / \mathrm{l})$; women, $<1.29 \mathrm{mmol} / \mathrm{l} \quad(0.50 \mathrm{~g} / \mathrm{l})$; (3) blood pressure: systolic $\geq 130 \mathrm{mmHg}$, diastolic $\geq 85 \mathrm{mmHg}$; (4) fasting glucose: $\geq 6 \cdot 1 \mathrm{mmol} / \mathrm{l}(1 \cdot 10 \mathrm{~g} / \mathrm{l})$; (5) abdominal obesity, as measured by waist circumference (WC). Abdominal obesity was confirmed if the WC was $>102 \mathrm{~cm}$ for men and $>88 \mathrm{~cm}$ for women. The state of insulin resistance in obese and diabetic participants was determined by homeostasis model assessment, determined by the following formula ${ }^{(27)}$ :

$$
\operatorname{insulin}(\mathrm{mU} / \mathrm{l}) \times \operatorname{glucose}(\mathrm{mmol} / \mathrm{l}) / 22.5 \text {. }
$$

\section{Sampling and analysis}

Venous blood samples were taken after an overnight fast (12 h). Serum glucose, TAG, total cholesterol, HDL and LDL levels were analysed by spectrophotometric techniques (Roche). Fructosamine was determined by colorimetric method using the technique of Flückiger et al. ${ }^{\text {(28) }}$. Insulin, cortisol, GH and adrenocorticotropin hormone (ACTH) levels were determined in the plasma. The hormones were quantified by RIA (BioMérieux). Anthropometric measurements were taken in order to calculate BMI according to the formula:

$$
\text { BMI }=\text { weight }(\mathrm{kg}) / \text { height }\left(\mathrm{m}^{2}\right) .
$$

\section{Statistical analysis}

Statistica 10.0 software was used for statistical calculations. ANOVA test was used for comparisons between all groups and controls. The results are presented as means and standard deviations, with a significance level, $P<0 \cdot 05$. For the study of $\mathrm{EBP}$, the data were processed by multivariate analysis to assess the contribution of three factors of the TFEQ. The Pearson correlation coefficient was used to quantify associations between BMI and WC, and each of the three test factors.

\section{Results}

\section{Eating behaviour pattern in healthy, obese and diabetic participants}

Obese participants had a higher disinhibition, associated with hunger, compared with healthy participants (Table 1). However, these participants show a low restraint score. Interestingly, there was no significant correlation between BMI and restraint in obese participants (Table 2). Disinhibition trait was correlated with BMI and WC in obese participants (Table 3).

The normal-weight and overweight diabetic participants exhibit a significant degree of restriction compared with controls (Table 1). The diabetics clearly exhibited three types of EBP, i.e. restraint, disinhibition and hunger (Table 1). We further observed that disinhibition was correlated with BMI and WC in diabetic participants; however, disinhibition was highly correlated with WC in overweight diabetics $v$. normal-weight diabetics. Overweight diabetics show a stronger correlation between BMI and disinhibition (Table 3).

\section{Anthropometric status}

BMI is more than $30 \mathrm{~kg} / \mathrm{m}^{2}$ in the obese group (Table 4). WC confirms an abdominal adiposity in obese participants (Table 4). WC parameters show that diabetic patients exhibit abdominal adiposity which is more pronounced in overweight diabetics than normal-weight diabetics.

\section{Glucose tolerance and insulin resistance}

Obese participants are normoglycaemic (Table 5). However, diabetic patients had fasting hyperglycaemia level more than $7 \mathrm{mmol} / \mathrm{l}$. Fructosamine (exceeding to $0.31 \mathrm{mmol} / \mathrm{l}$ ) followed the same pattern. This reflects the chronic state of hyperglycaemia in diabetic patients. In obese participants, fructosamine levels are normal, concomitant with normoglycaemia levels in fasting state.

In obese and diabetic patients, hyperinsulinaemic state was observed, comparatively with healthy participants (Table 5); this state was exacerbated in overweight diabetics. Insulin

Table 3. Correlation of disinhibition with BMI and waist circumference

\begin{tabular}{|c|c|c|c|}
\hline \multicolumn{4}{|c|}{ Disinhibition ( $r$ value) } \\
\hline & Obese $(n 130)$ & $\begin{array}{l}\text { Normal-weight } \\
\text { diabetics }(n 76)\end{array}$ & $\begin{array}{c}\text { Overweight } \\
\text { diabetics ( } n \text { 94) }\end{array}$ \\
\hline$W C(\mathrm{~cm})$ & $0.47^{\star *}$ & $0.34^{*}$ & $0.81^{* \star *}$ \\
\hline BMI $\left(\mathrm{kg} / \mathrm{m}^{2}\right)$ & $0.51^{\star *}$ & $0.38^{*}$ & $0.53^{* *}$ \\
\hline
\end{tabular}
(WC) in obese and diabetic participants 
Table 4. Anthropometric status in obese and diabetic participants

(Mean values and standard deviations)

\begin{tabular}{|c|c|c|c|c|c|c|c|c|}
\hline \multirow{3}{*}{$\begin{array}{l}\text { Anthropometric } \\
\text { parameters }\end{array}$} & \multirow{2}{*}{\multicolumn{2}{|c|}{$\begin{array}{l}\text { Healthy } \\
\text { participants } \\
(n 110)\end{array}$}} & \multirow{2}{*}{\multicolumn{2}{|c|}{$\begin{array}{c}\text { Obese } \\
\text { participants } \\
(n 130)\end{array}$}} & \multicolumn{4}{|c|}{ Diabetic participant } \\
\hline & & & & & \multicolumn{2}{|c|}{$\begin{array}{c}\text { Normal weight } \\
(n 76)\end{array}$} & \multicolumn{2}{|c|}{$\begin{array}{l}\text { Overweight } \\
\text { (n 94) }\end{array}$} \\
\hline & Mean & SD & Mean & SD & Mean & SD & Mean & SD \\
\hline $\mathrm{BMI}\left(\mathrm{kg} / \mathrm{m}^{2}\right)$ & 24 & 0.22 & $33^{\star \star \star}$ & 0.84 & 23.75 & 0.43 & $28.48^{\star \star}$ & 1.65 \\
\hline WC $(\mathrm{cm})$ & 80 & $1 \cdot 18$ & $107^{\star \star \star}$ & 1.42 & $94^{\star \star}$ & 1.74 & $107^{\star \star \star}$ & 0.33 \\
\hline
\end{tabular}

levels are significantly higher in these participants than in controls. Homeostasis model assessment values are very high in both diabetic and obese participants, the highest being in the overweight diabetic group (Table 5).

\section{Haemodynamic and atherogenic lipid status}

Table 5 shows that dyslipidaemia is apparent in both obese and diabetic patients, particularly in overweight diabetics. TAG and total cholesterol levels are enhanced significantly compared with healthy participants. Systolic blood pressure was significantly higher in obese and all diabetic participants than in healthy controls.

\section{Cortisol, adrenocorticotropin hormone and growth hormone concentrations}

Serum cortisol and ACTH concentrations are altered in obese and diabetic patients. Table 6 shows that cortisol level is higher in obese and diabetic participants than in controls (an increase of $22.22 \%$ in obese participants and 33\% in normal-weight diabetics), overweight diabetics show a highest increase. ACTH levels are decreased by $41.66 \%$ in obese participants, $57 \%$ in normal-weight diabetics and $70 \%$ in overweight diabetics compared with healthy participants. The GH secretion shows a decrease of $53.42 \%$ in obese participants and $64 \%$ in overweight diabetic participants, compared with control participants. No significant difference was observed in GH secretion between normal-weight diabetic and healthy participants (Table 6).

\section{Discussion}

Food consumption is a behavioural aspect that regulates energy metabolism of the organism. In the present study, we observed the absence of dietary restraint, although disinhibition and hunger were increased in obese participants, indicating the presence of hyperphagic type of EBP in these individuals. Disinhibition predicts the compulsive type of food intake ${ }^{(29)}$. Generally, individuals with high disinhibition have the tendency to overeat in response to different stimuli. In obese and type 2 diabetic participants, we observed a significant correlation between disinhibition scores and BMI, and WC, although overweight diabetics showed the strongest correlation. The present study corroborates several reports that have demonstrated a relationship between disinhibition and high BMI in obese participants ${ }^{(30-37)}$. Our observations strengthen the notion that disinhibition, a key component of obesity, would be a predictor of weight gain ${ }^{(33,38,39)}$. With regard to the physiological explanation of disinhibition, it is possible that there might be low circulating concentrations of YY peptide in obese participants ${ }^{(40)}$. Martins et al. ${ }^{(41)}$

Table 5. Metabolic parameters in obese and diabetic participants

(Mean values and standard deviations)

\begin{tabular}{|c|c|c|c|c|c|c|c|c|}
\hline \multirow[b]{3}{*}{ Parameters } & \multirow{2}{*}{\multicolumn{2}{|c|}{$\begin{array}{l}\text { Healthy } \\
\text { participants } \\
(n 110)\end{array}$}} & \multirow{2}{*}{\multicolumn{2}{|c|}{$\begin{array}{c}\text { Obese } \\
\text { participants } \\
(n 130)\end{array}$}} & \multicolumn{4}{|c|}{ Diabetic participants } \\
\hline & & & & & \multicolumn{2}{|c|}{$\begin{array}{l}\text { Normal weight } \\
\quad(n 76)\end{array}$} & \multicolumn{2}{|c|}{ Overweight ( $n$ 94) } \\
\hline & Mean & SD & Mean & SD & Mean & SD & Mean & SD \\
\hline Glycaemia (mmol/l) & $4 \cdot 88$ & 0.01 & $5 \cdot 27$ & 0.041 & $9 \cdot 91^{\star \star \star}$ & 1.05 & $10 \cdot 31^{\star \star \star}$ & 0.92 \\
\hline HOMA index & 2 & 0.1 & $6^{\star \star \star}$ & 0.4 & $11 \cdot 97^{\star \star \star}$ & 1.92 & $17 \cdot 15^{\star \star \star}$ & 3.51 \\
\hline Fructosamine $(\mathrm{mmol} / \mathrm{l})$ & 0.19 & 0.08 & 0.23 & 0.01 & $0.32^{\star \star}$ & 0.04 & $0 \cdot 38^{\star \star \star}$ & 0.01 \\
\hline Insulinaemia $(\mu \mathrm{U} / \mathrm{l})$ & 8 & 1 & $25^{\star \star \star}$ & 3 & $25 \cdot 92^{\star \star \star}$ & 3.43 & $39 \cdot 70^{* * *}$ & 6.92 \\
\hline $\mathrm{TAG}(\mathrm{mmol} / \mathrm{l})$ & 0.87 & 0.22 & $1.60^{\star \star \star}$ & $0 \cdot 17$ & $1.66^{\star \star \star}$ & 0.26 & $1 \cdot 76^{\star \star \star}$ & 0.26 \\
\hline Total cholesterol $(\mathrm{mmol} / \mathrm{l})$ & 4.11 & 0.30 & $5 \cdot 05^{\star}$ & 0.77 & $4.96^{\star}$ & 0.43 & $5.49^{*}$ & 0.48 \\
\hline HDL-cholesterol (mmol//) & 1.42 & 0.44 & $1.08^{*}$ & 0.22 & $1.01^{*}$ & 0.10 & $1^{*}$ & 0.06 \\
\hline LDL-cholesterol (mmol/l) & 2.32 & 0.80 & $2.99^{\star}$ & 0.22 & $2 \cdot 95^{\star}$ & 0.30 & $3 \cdot 62^{\star \star \star}$ & 0.22 \\
\hline Systolic blood pressure $(\mathrm{mmHg})$ & 113 & 14 & $128^{\star}$ & 12 & $127^{\star}$ & 11 & $133^{\star}$ & 11 \\
\hline Diastolic blood pressure $(\mathrm{mmHg})$ & 75 & 5 & 79 & 6 & 79 & 4 & 81 & 4 \\
\hline
\end{tabular}

HOMA, homeostasis model assessment.

Mean values were significantly different from that of the healthy participant group: ${ }^{\star} P<0.05,{ }^{\star *} P<0.01,{ }^{* \star *} P<0.001$. 
Table 6. Hormone levels in obese and diabetic participants

(Mean values and standard deviations)

\begin{tabular}{|c|c|c|c|c|c|c|c|c|}
\hline \multirow[b]{3}{*}{ Parameters } & \multirow{2}{*}{\multicolumn{2}{|c|}{$\begin{array}{l}\text { Healthy } \\
\text { participants } \\
(n 110)\end{array}$}} & \multirow{2}{*}{\multicolumn{2}{|c|}{$\begin{array}{c}\text { Obese } \\
\text { participants } \\
(n 130)\end{array}$}} & \multicolumn{4}{|c|}{ Diabetic participants } \\
\hline & & & & & \multicolumn{2}{|c|}{$\begin{array}{c}\text { Normal weight } \\
(n 76)\end{array}$} & \multicolumn{2}{|c|}{$\begin{array}{l}\text { Overweight } \\
(n 94)\end{array}$} \\
\hline & Mean & $\overline{S D}$ & Mean & $\overline{S D}$ & Mean & SD & Mean & SD \\
\hline Cortisol (nmol/l) & 189 & 3 & $231^{\star \star \star}$ & 9 & $251 \cdot 11^{\star \star *}$ & 9 & $439 \cdot 49^{\star \star \star}$ & 11 \\
\hline ACTH $(\mathrm{pg} / \mathrm{ml})$ & 48 & 0.80 & $28^{\star \star \star}$ & 7 & $20 \cdot 6^{\star \star *}$ & $5 \cdot 80$ & $14 \cdot 55^{\star \star \star}$ & 2.3 \\
\hline $\mathrm{GH}(\mathrm{mU} / \mathrm{l})$ & 1.46 & 0.11 & $0.68^{\star \star \star}$ & 0.02 & 1.44 & 0.44 & $0.52^{\star * \star}$ & 0.28 \\
\hline
\end{tabular}

$\mathrm{ACTH}$, adrenocorticotropin hormone; $\mathrm{GH}$, growth hormone.

${ }^{\star * *}$ Mean values were significantly different from that of the healthy participant group $(P<0.001)$.

demonstrated that decreased YY peptide concentrations in the postprandial state might create a susceptibility to overconsumption of food and increased risk for weight gain ${ }^{(41)}$.

All the diabetic patients exhibited three types of eating patterns, as reported by Ryan et $a l^{(42)}$. Diabetics seem to deliberately restrict their food intake to control their weight gain and blood glucose levels. While rigid restraint has been associated with a greater tendency to overeat and poorer weight control, flexible restraint predicts better weight control and reduced overeating ${ }^{(43)}$. We observed that diabetic patients controlled their food intake to avoid pathological complications. It has been proposed that the food restraint should be considered as a cognitive causal factor in weight gain ${ }^{(44)}$ and onset of $\mathrm{EBP}^{(45)}$

WC was positively correlated with obesity and diabetes in the present study. An increase in WC has been shown to contribute to the pathogenesis of the metabolic syndrome ${ }^{(46)}$. Freedland $^{(47)}$ showed that obesity was positively correlated with the expansion of the volume of visceral adipose tissue, and visceral obesity was strongly associated with the metabolic syndrome. In the present study, the homeostasis model assessment index confirms the state of insulin resistance in obese and diabetic groups. The relationship between homeostasis model assessment, WC and insulin resistance in these subjects is consistent with previous literature $^{(48)}$. Nevertheless, glucose and fructosamine were normal in obese participants. Obese and diabetic participants exhibited elevated TAG levels, associated with a decrease in HDL concentrations, and an increase in LDL concentrations. LOW HDL concentration has been reported to be associated with a subsequent risk of type 2 diabetes, with a greater effect in the presence of obesity ${ }^{(49)}$. The metabolic syndrome and type 2 diabetes have been associated with decreased HDL concentrations, hypertriacylglycerolaemia and obesity ${ }^{(50)}$.

With regard to the concentrations of cortisol and ACTH which are, respectively, higher and lower in obese and diabetic, particularly overweight diabetic, participants than controls, we can state that the former might exert a negative feedback control on the latter during these pathologies. In addition, high circulating cortisol may not be secreted from the adrenal glands as ACTH is low; however, other peripheral tissues, such as adipose tissue, may be the site of its production as suggested elsewhere ${ }^{(51)}$. In view of anthropometric and metabolic alterations associated with insulin resistance in diabetic participants, we suggest that GC might be involved in the genesis of the metabolic syndrome, as reported by Iovino et al. ${ }^{(51)}$, in type 2 diabetic patients. Growing evidence suggests that the metabolic syndrome and central obesity may result from an increased availability of GC at the tissue level (mainly the liver and the adipose tissue) ${ }^{(52)}$. GC have been reported to exert an action on the differentiation of preadipocytes into adipocytes, which might aggravate adiposity ${ }^{(53)}$. Conversely, GC may also increase the activity of $11 \beta$-hydroxysteroid dehydrogenase- 1 $(11 \beta-H S D-1)^{(54)}$. Hence, $11 \beta-H S D-1$ will produce cortisol that will either induce the proliferation of preadipocytes or promote the differentiation of these cells into adipocytes ${ }^{(55)}$. The present results on the decrease in GH levels in obese and overweight type 2 diabetic participants indicate that reduced GH might be responsible for high $11 \beta$-HSD-1 activity and would contribute to high GC levels as reported elsewhere in obese participants ${ }^{(56)}$.

In conclusion, the present findings show the implication of EBP in obesity and diabetes, where disinhibition was strongly associated with weight gain and insulin resistance. EBP may lead to obesity and metabolic syndrome, associated with hyperactivity of pancreatic $\beta$ cells and adrenal and pituitary glands. The counselling of EBP may improve metabolic, hormonal and anthropometric parameters. Different strategies, oriented to the cognitive control of food intake, should be considered key tools in controlling obesity and associated pathologies.

\section{Acknowledgements}

The present study was supported by grants from the National Research Program (PNR no. 208 and 41/ANDRS/2011), the National Administration of Algerian Higher Education and Scientific Research (DG-RSDT) and a bilateral Franco-Algerian collaborative project 'Tassili' (grant no. 12MDU855). This study received no specific grant from any commercial or notfor-profit sectors. The funders had no role in the design and analysis of the study or in the writing of this article.

The authors' contributions are as follows: N. A. K. and E. A. K. designed the study (project conception, development of overall research plan and study oversight); H. B. conducted the study (hands-on conduct of the experiments and data collection); N. A. K., E. A. K. and H. B. wrote the manuscript; E. M. H. and G. K., B. O. provided the facilities in the sample 
collections. All authors have read and approved the final content of the manuscript.

None of the authors has any conflict of interest to declare.

\section{References}

1. Luquet S \& Cruciani-Guglielmacci C (2009) Le contrôle central de la balance énergétique (Energy balance control by the central nervous system). Cah Nutr Diet 44, 17-25.

2. Denis RG, Cansell C, Castel J, et al. (2013) Circuits de la récompense et prise alimentaire (Reward neuronal network and food intake). Méd Maladies Métabol 1, 13-21.

3. Eckel RH, Grundy SM \& Zimmet PZ (2005) The metabolic syndrome. Lancet 365, 1415-1428.

4. Karra E \& Batterham RL (2010) The role of gut hormones in the regulation of body weight and energy homeostasis. Mol Cell Endocrinol 316, 120-128.

5. Lamri L, Gripiotis E \& Ferrario A (2014) Diabetes in Algeria and challenges for health policy: a literature review of prevalence, cost, management and outcomes of diabetes and its complications. Global Health 10, 11.

6. Esparza-Romero J, Valencia ME, Martinez ME, et al. (2010) Differences in insulin resistance in Mexican and U.S. Pima Indians with normal glucose tolerance. $J$ ClinEndocrinol Metab 95, E358-E362.

7. Esposito K, Maiorino MI, Ciotola M, et al. (2009) Effects of a Mediterranean-style diet on the need for antihyperglycemic drug therapy in patients with newly diagnosed type 2 diabetes: a randomized trial. Ann Intern Med 151, 306-314.

8. Salas-Salvado J, Bullo M, Babio N, et al. (2011) Reduction in the incidence of type 2 diabetes with the Mediterranean diet: results of the PREDIMED-Reus nutrition intervention randomized trial. Diabetes Care 34, 14-19.

9. Herman CP \& Mack D (1975) Restrained and unrestrained eating. J Pers 43, 647-660.

10. McLean JA, Barr SI \& Prior JC (2001) Cognitive dietary restraint is associated with higher urinary cortisol excretion in healthy premenopausal women. Am J Clin Nutr 73, 7-12.

11. Boullu-Ciocca S, Verger P, Bocquier A, et al. (2005) Corticotropic axis and chronic stress in abdominal obesity and metabolic syndrome. Presse Med 34, 1646-1653.

12. Brindley DN \& Rolland Y (1989) Possible connections between stress, diabetes, obesity, hypertension and altered lipoprotein metabolism that may result in atherosclerosis. Clin Sci (Lond) 77, 453-461.

13. Duong M, Cohen JI \& Convit A (2012) High cortisol levels are associated with low quality food choice in type 2 diabetes. Endocrine 41, 76-81.

14. Thakore JH \& Dinan TG (1994) Growth hormone secretion: the role of glucocorticoids. Life Sci 55, 1083-1099.

15. Senaris RH, Lago F, Coya R, et al. (1996) Regulation of hypothalamic somatostatin, growth hormone-releasing hormone, and growth hormone receptor messenger ribonucleic acid by glucocorticoids. Endocrinology 137, 5236-5241.

16. Evans RM, Bimberg NC \& Rosenfeld MG (1992) Glucocorticoid and thyroid hormones transcriptionally regulate growth hormone gene expression. Proc Natl Acad Sci U S A 79, 7659-7663.

17. Korytko AI \& Cuttler L (1997) Thyroid hormone and glucocorticoid regulation of pituitary growth hormone-releasing hormone receptor gene expression. J Endocrinol 152, R13-R17.

18. Allen D, Julius J, Breen T, et al. (1998) Treatment of glucocorticoid-induced growth suppression with growth hormone. National Cooperative Growth Study. J Clin Endocrinol Metab 83, 2824-2829.
19. Miller TL \& Mayo KE (1999) Glucocorticoids regulate pituitary growth hormone-releasing hormone receptor messenger ribonucleic acid expression. Endocrinology 138, $2458-2465$.

20. Hochberg Z (2002) Mechanisms of steroid impairment of growth. Horm Res 58, 33-38.

21. Stunkard AJ \& Messick S (1985) The three-factor eating questionnaire to measure dietary restraint, disinhibition and hunger. J Psychosom Res 29, 71-83.

22. Polivy J, Herman CP \& Coelho JS (2008) Caloric restriction in the presence of attractive food cues: external cues, eating, and weight. Physiol Behav 94, 729-733.

23. Calderon C, Forns M \& Varea V (2010) Implication of the anxiety and depression in eating disorders of young obese. Nutr Hosp 25, 641-647.

24. French SA, Mitchell NR, Finlayson G, et al. (2014) Questionnaire and laboratory measures of eating behavior. Associations with energy intake and BMI in a community sample of working adults. Appetite 72, 50-58.

25. Athyros VG, Ganotakis ES, Elisaf M, et al. (2005) The prevalence of the metabolic syndrome using the National Cholesterol Educational Program and International Diabetes Federation definitions. Curr Med Res Opin 21, 1157-1159.

26. Balkau B, Valensic P, Eschwègea E, et al. (2007) A review of the metabolic syndrome. Diabetes Metab 33, 405-413.

27. Matthews DR, Hosker JP \& Rudenski AS (1985) Homeostasis model assessment: insulin resistance and $\beta$-cell function from fasting plasma glucose and insulin concentrations in man. Diabetologia 28, 412-419.

28. Flückiger R, Woodtli T \& Berger W (1987) Evaluation of the fructosamine test for the measurement of plasma protein glycation. Diabetologia 30, 648-652.

29. Galanti K, Gluck ME \& Geliebter A (2007) Test meal intake in obese binge eaters in relation to impulsivity and compulsivity. Int J Eat Disord 40, 727-732.

30. French SA, Epstein LH, Jeffery RW, et al. (2012) Eating behavior dimensions. Associations with energy intake and body weight. A review. Appetite 59, 541-549.

31. Esteves EA, Costa MO, Moreno LG, et al. (2012) Dietary restraint, dietary disinhibition and susceptibility to hunger of normal weight and overweight women. Rev Esp Nutr Hum Diet 16, 10-15.

32. Rideout CA \& Barr SI (2009) Restrained eating vs trying to lose weight: how are they associated with body weight and tendency to overeat among postmenopausal women? J Am Diet Assoc 109, 890-893.

33. Bellisle F, Clément K, Le Barzic M, et al. (2004) The Eating Inventory and body adiposity from leanness to massive obesity: a study of 2509 adults. Obes Res 12, 2023-2030.

34. O'Neill BV, Bullmore ET, Miller S, et al. (2012) The relationship between fat mass, eating behaviour and obesity-related psychological traits in overweight and obese individuals. Appetite 59, 656-661.

35. Savage JS, Hoffman L \& Birch LL (2009) Dieting, restraint, and disinhibition predict women's weight change over $6 \mathrm{y}$. Am J Clin Nutr 90, 33-40.

36. Hays NP \& Roberts SB (2008) Aspects of eating behaviors "disinhibition" and "restraint" are related to weight gain and BMI in women. Obesity (Silver Spring) 16, 52-58.

37. Wadden TA, Foster GD, Sarwer DB, et al. (2004) Dieting and the development of eating disorders in obese women: results of a randomized controlled trial. Am J Clin Nutr 80, 560-568.

38. Chaput JP, Leblanc C, Perusse L, et al. (2009) Risk factors for adult overweight and obesity in the Quebec Family Study: 
have we been barking up the wrong tree? Obesity (Silver Spring) 17, 1964-1970.

39. Yanovski SZ (2003) Binge eating disorder and obesity in 2003: could treating an eating disorder have a positive effect on the obesity epidemic? Int J Eat Disord 34, S117-S120.

40. Bottcher G, Sjolund K, Ekbad E, et al. (1984) Coexistence of peptide YY and glicentin immunoreactivity in endocrine cells of the gut. Regul Pept 8, 261-266.

41. Martins C, Robertson MD \& Morgan LM (2010) Impact of restraint and disinhibition on PYY plasma levels and subjective feelings of appetite. Appetite 55, 208-213.

42. Ryan M, Gallanagh J, Livingstone MB, et al. (2008) The prevalence of abnormal eating behaviour in a representative sample of the French diabetic population. Diabetes Metab 34, 581-586.

43. Westenhoefer J, Von Falck B, Stellfeldt A, et al. (2004) Behavioural correlates of successful weight reduction over 3 y. Results from the Lean Habits Study. Int J Obes Relat Metab Disord 28, 334-345.

44. Allen Kl, Byrne SM, La Puma M, et al. (2008) The onset and course of binge eating in 8- to 13-year-old healthy weight, overweight and obese children. Eat Behav 9, 438-446.

45. Rigaud D (2009) Nutrition. Changing our food behaviours. Rev Prat 59, 37-39.

46. Tartaglia LA, Dembski M, Weng X, et al. (1995) Identification and expression cloning of a leptin receptor OB-R. Cell 83, $1263-1271$.

47. Freedland ES (2004) Role of a critical visceral adipose tissue threshold (CVATT) in metabolic syndrome: implications for controlling dietary carbohydrates: a review. Nutr Metab 1, 12-16.

48. Ribeiro-filho FF, Faria AN, Kohlmann NEB, et al. (2003) Two-hour insulin determination improves the ability of abdominal fat measurement to identify risk for the metabolic syndrome. Diabetes Care 26, 1725-1730.

49. Gautier A, Balaku B, Lange C, et al. (2010) DESIR Study Group Risk factors for incident type 2 diabetes in individuals with a BMI of $<27 \mathrm{~kg} / \mathrm{m}^{2}$ : the role of $\boldsymbol{\gamma}$-glutamyltransferase. Data from an Epidemiological Study on the Insulin Resistance Syndrome (DESIR). Diabetologia 53, $247-253$

50. Vergès B, Brun JM, Vaillant G, et al. (1992) Influence of obesity and hypertriglyceridemia on low HDL2-cholesterol level and its relationship with prevalence of atherosclerosis in type 2 diabetes. Diabetes Metab 18, 289-297.

51. Iovino A, Paquot N \& Scheen AJ (2010) Reduction of obesityrelated metabolic risk by modulating tissue exposition to cortisol. Rev Med Suisse 6, 1608-1612.

52. Anagnostis P, Athyros VG, Tziomalos K, et al. (2009) Clinical review: the pathogenetic role of cortisol in the metabolic syndrome: a hypothesis. J Clin Endocrinol Metab 94, 2692-2701.

53. Paulmyer-lacroix O, Boullu-ciocca S, Oliver C, et al. (2003) Glucocorticoïdes, 11ß-hydroxystéroïde déshydrogénase de type 1 et obésité viscérale (Glucocorticoids, 11ß-hydroxysteroid dehydrogenase type 1 , and visceral obesity). Med Sci 19, 473-476.

54. Baudrand R, Dominguez JM, Carvajal CA, et al. (2011) Overexpression of hepatic $5 \alpha$-reductase and $11 \beta$-hydroxysteroid dehydrogenase type 1 in visceral adipose tissue is associated with hyperinsulinemia in morbidly obese patients. Metabolism 60, 1775-1780.

55. Weaver JU, Thaventhiran L \& Noonan N (1994) The effect of growth hormone replacement on cortisol metabolism and glucocorticoid sensitivity in hypopituitary adults. Clin Endocrinol 41, 639-648.

56. Bujalska IJ, Walker EA, Hewinson M, et al. (2002) A switch in dehydrogenase to reductase activity of $11 \beta$-hydroxysteroid dehydrogenase type 1 upon differentiation of human omental adipose stromal cells. J Clin Endocrinol Metab 87, 1205-1210. 